\title{
Spatial and seasonal changes in benthic macrofauna from two dissipative sandy beaches in eastern Brazil)*
}

\author{
Mariane Silva Coutinho ${ }^{I * *}$, Angelo Fraga Bernardino ${ }^{l}$
}

\author{
${ }^{1}$ Universidade Federal do Espírito Santo - Departamento de Oceanografia e Ecologia \\ (Avenida Fernando Ferrari, 514 - Vitória - Espírito Santo, 29075-910 - Brazil) \\ ** Corresponding author: marianecoutinho8@hotmail.com
}

\section{ABSTRACT}

Sandy beaches are dynamic ecosystems with strong interaction of sediments, waves and tidal energy, with marked effects on benthic assemblages. Although there are numerous efforts in understanding spatial-temporal variation of benthic macrofauna on sandy beaches along the southern and southeastern Marine Ecoregions in Brazil, there is poor sampling along beaches of the Eastern Marine Ecoregion (EME). Here we examined spatial and temporal scales of variability in benthic macrofauna $(>500$ $\mu \mathrm{m})$ through a hierarchical sampling of two dissipative sandy beaches within the EME between two seasons (winter 2011 and summer 2012). We tested the hypothesis that spatial changes (i.e., meters to hundreds of meters scales) in the structure of benthic assemblages will be more pronounced compared to the weak seasonal fluctuations at this tropical region. We found weak temporal and spatial changes in sediment grain size and beach slope, but differences in macrofaunal assemblages were evident. Contrary to our hypothesis, hierarchical sampling indicated significant changes in macrofaunal composition and density at multiple local scales (meters to hundreds of meters) and on seasonal scales. The macrofauna density and composition was directly related to changes on the sediment organic matter and grain size.

Descriptors: Sandy beaches, Macrofauna, Benthic ecology, Eastern Marine Ecoregion.

\section{RESUMO}

Praias arenosas são ambientes dinâmicos com interação entre sedimento, energia de ondas e marés, com marcantes efeitos sobre assembléias bentônicas. Existem numerosos esforços no entendimento da variação espaço-temporal da macrofauna bentônica em praias no Brasil, sendo a maioria concentrados na Ecorregião Marinha Sudeste e Rio Grande $\left(20^{\circ} \mathrm{S}\right.$ a $\left.35^{\circ} \mathrm{S}\right)$, mas limitada amostragem em praias tropicais na Ecoregião Marinha Leste (EML). Este estudo examinou as escalas de variabilidade espaço-temporal da macrofauna bentônica $(>500 \mu \mathrm{m})$ através de amostragem hierárquica em duas praias dissipativas dentro da EML em duas estações (inverno de 2011/verão de 2012). Testou-se a hipótese que mudanças espaciais (escala de metros a centenas de metros) na estrutura das assembléias bentônicas são menos pronunciadas em comparação com as fracas flutuações sazonais nesta região tropical. Foram encontradas pequenas mudanças espaço-temporais na granulometria e perfil de praia, mas com evidentes diferenças nas assembléias macrofaunais. Contrariando a hipótese deste estudo, a amostragem hierárquica indicou mudanças significativas na composição e densidade da macrofauna em múltiplas escalas locais (metros a centenas de metros) e em escalas temporais. A densidade e composição da macrofauna está relacionada com mudanças no teor de matéria orgânica do sedimento e tamanho do grão.

Descritores: Praias arenosas, Macrofauna, Ecologia Bêntica, Ecorregião Marinha Leste.

Received: November 9, 2015

Approved: July 7, 2017

* Paper presented in the International Sandy Beach Symposium, 7. 2015, Ilhabela, São Paulo, Brazil . 


\section{INTRODUCTION}

Sandy beaches are dynamic ecosystems physically structured by sediment particle size, waves and tidal energy. They are at the transition between continents and oceans and have societal and ecological importance. Sandy beaches dominate the world's coastlines in temperate and tropical zones, are important sites for human recreation maintaining many coastal economies around the world, and provide habitat for a diversity of terrestrial and marine life (MCLACHLAN; ERASMUS, 1983; ALONGI, 1998; MCLACHLAN; BROWN, 2006; SCHLACHER et al., 2007; DEFEO; MCLACHLAN, 2013). These ecosystems host a diversity of terrestrial and marine life, with multiple ecological functions including recycling of nutrients, supporting coastal fisheries though benthic production, and providing nesting sites for turtles and shorebirds (MCLACHLAN, 1989; MCLACHLAN; BROWN, 2006; SCHLACHER et al. 2007).

Sandy beaches differ greatly on the interaction of physical parameters according to spatial and temporal changes in wave climate, sediment types and tidal regimes, which result in beach types with variable morphology. Spatial differences in sandy beach morphodynamics vary greatly; from microtidal reflective beaches that are usually narrow, steep and with coarse sand, to macrotidal dissipative beaches that are typically wide and flat, under high wave energy resulting in a gentle slope and fine sand (MCLACHLAN; BROWN, 2005; DEFEO; MCLACHLAN, 2005). These spatial morphodynamic changes strongly influence benthic assemblage abundance, composition and diversity (e.g. BARROS et al., 2001; BARBOSA et al., 2012; CARCEDO et al., 2014). At larger scales, dissipative beaches typically have higher diversity and biomass due to less wave energy conditions, if compared to reflective beaches (DEFEO; MCLACHLAN, 2005; BARBOSA et al., 2012). Spatial changes within alongshore and across-shore gradients are also important in some sand beaches, and reflect meterscale gradients of physical and biological factors including food availability, wave energy and sediment transport (DEFEO; MCLACHLAN, 2005).

Temporal changes on beach morphodynamics, food availability and climate stressors are also important to benthic macrofaunal assemblages at sand beaches (DEFEO; MCLACHLAN, 2005). Episodic or continuous physical stressors, including stochastic physical events (e.g. wave climate), increasing temperatures and a combination of local-scale chemical and biological variables can rapidly change population dynamics of macrofaunal organisms on sandy beaches (DEFEO; MCLACHLAN, 2005; CISNEROS et al., 2011). In Brazil, there has been a continuous decadal increase on average temperatures on all Marine Ecoregions, with potential impacts on several coastal ecosystems including sand beaches (BERNARDINO et al., 2015; 2016; AMARAL et al., 2016). On dissipative sandy beaches, the seasonal changes on sediment organic availability, nutrients and salinity are highly important to macrofaunal abundance and diversity, with increases in abundance and richness in periods of higher organic availability (CISNEROS et al., 2011). Therefore, temporal and spatial changes in beach productivity, temperature and morphodynamics are likely to cause strong impacts on its associated benthic fauna.

Sandy beaches are among the most vulnerable coastal ecosystems as they are under stress from terrestrial and marine impacts (DEFEO et al., 2009). In Brazil, human interference and tourism are the main sources of disturbance to these ecosystems (VELOSO et al., 2008). The urban development transformed the coastal landscape with large expanses of beaches and removal of dunes to allow civil construction including barriers to protect the coastline, which markedly change sediment transport and modified erosion processes (AMARAL et al., 2016; MUEHE, 2003; 2006). Human impacts also include tourism, which increase the movement of vehicles and trampling, eliminating species and interfering in the breeding and nesting of birds (VELOSO et al., 2008; DEFEO et al., 2009; VIEIRA et al., 2012). These impacts result in marked changes in beach morphodynamics, altering sediment composition and beach slope leading to further impacts on the benthos (AMARAL et al., 2016; DEFEO et al., 2009).

Brazil has more than seven thousand kilometers of coastline, with numerous sandy beaches. These ecosystems have been widely studied along the Brazilian coast, with most studies in the Southeastern and Rio Grande Marine Ecoregions (MMA, 2007; SPALDING et al., 2007, AMARAL et al., 2016). The Eastern Marine Ecoregion of Brazil (EME) has been very poorly studied with respect to its sandy beach fauna, including its biodiversity and ecological patterns, which prevent assessment of baseline status in face of regional and global impacts on these ecosystems. For example, a recent (October 2015) environmental disaster spilled an unknown amount of mine tailings on the Eastern Brazilian 
coast with impacts to coastal ecosystems in the region (MARTA-ALMEIDA et al., 2016; GOMES et al., 2017). Several other pressures to sand beaches occur in the region, including urbanization, ports and tourism. In this context, this study aimed to identify and describe spatial and temporal patterns of benthic macrofaunal assemblages of two sandy beaches within the EME. Through a hierarchical spatial sampling, in two time periods (winter 2011 and summer 2012) at two beaches with similar morphology, we tested the hypothesis that spatial variations (i.e. scales of meters to hundreds of meters) in the structure of benthic assemblages would be more significant and directly related to the abiotic variables if compared to low seasonal fluctuations in temperature, organic availability and beach morphology.

\section{MATERIAL AND METHODS}

STUDY AREA

The study site is located within the EME characterized by a tropical climate with mean temperatures of $22-24^{\circ} \mathrm{C}$ and annual rainfall of 1000-1600 mm (Figure 1, SPALDING et al., 2007; BERNARDINO et al.., 2015). Wind direction is predominantly from the East - Northeast (NE trade winds), but high intensity SE winds associated with cold fronts occasionally reach the area. The coast has a microtidal semidiurnal tidal regime $(<2 \mathrm{~m})$. Two sandy beaches located within an environmental protection area were sampled, the Putiri beach (19॰54'20's, 40 5'54'”) and Dos Quinze beach (19 53'45.6"S, 40 $\left.05^{\prime} 31.3^{\prime \prime} \mathrm{W}\right)$. Both sandy beaches show retrogression due to the small river intake and abrasive vulnerability of carbonate sands, being characterized as exposed and semi-exposed beaches with bioclastic sediments (ALBINO et al., 2001). Abrasion terraces are located from the inner continental shelf to coastal shores, which dissipate the energy of the incident waves, reduce wave height and result in small seasonal topographic variation of beach profiles.

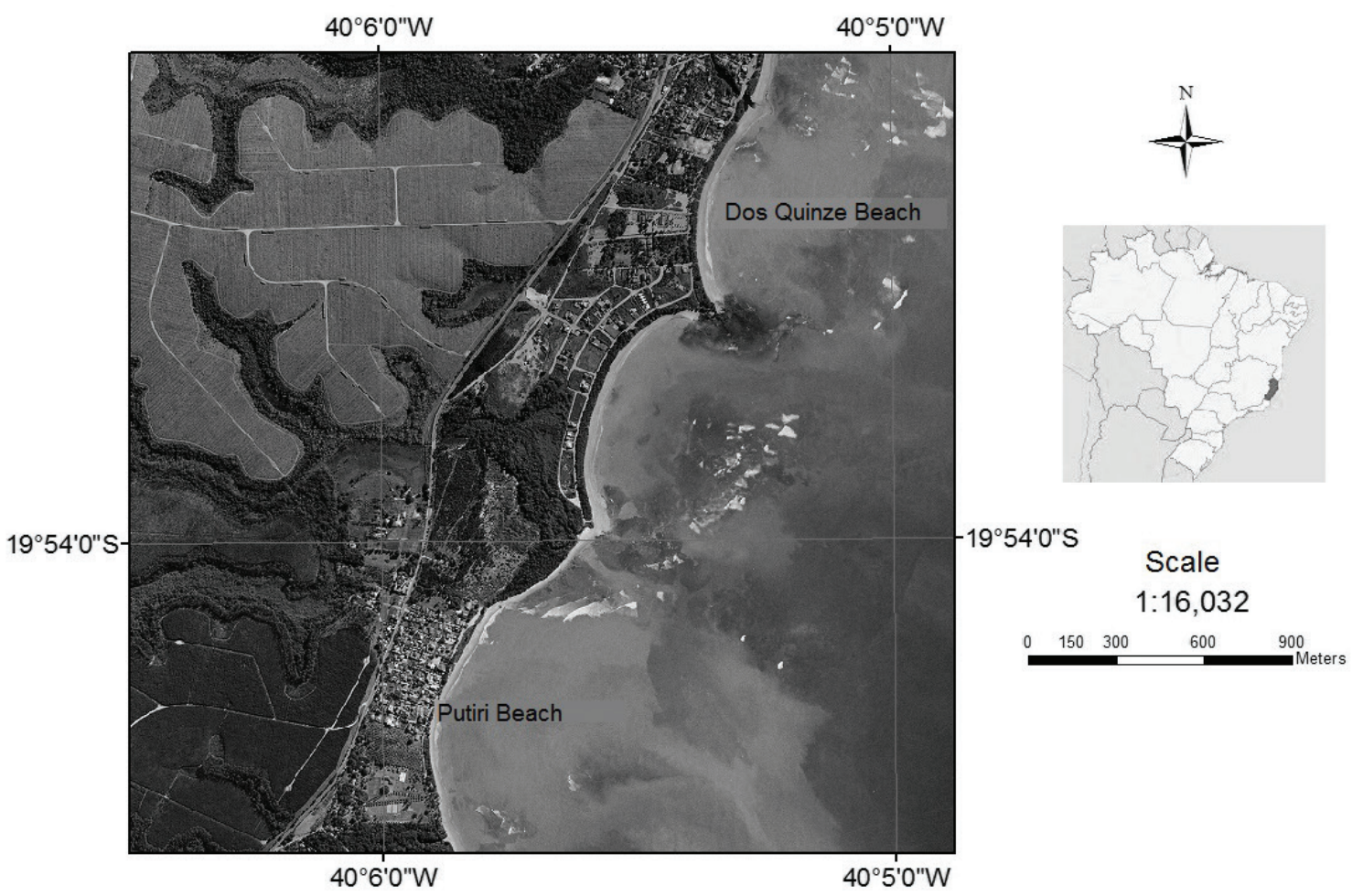

Figure 1. Location of the two sand beaches sampled in the EME. 


\section{SAMPLING AND LABORATORY PROCEDURES}

Sampling occurred during a year along six campaigns on each beach, with three random campaigns in each season (Winter 2011 and Summer 2012). Benthic macrofaunal assemblages were sampled from each beach in a hierarchical design. Longitudinal sampling was randomly divided along three areas (A1, A2 and A3, Figure 2), separated by at least 50 meters that were sampled in each campaign. Each area was subdivided into three random transects perpendicular to the shoreline, which were systematically sampled at every 4 meters, resulting in 8-9 replicates (each with $0,0314 \mathrm{~m}^{2}, 20 \mathrm{~cm}$ depth) distributed along the intertidal area, totaling 894 samples of fauna (14 $\mathrm{m}^{2}$ sampled in each beach). Macrofaunal samples were fixed in $4 \%$ formalin in the field, washed on a $500 \mu \mathrm{m}$ mesh and preserved on $70 \% \mathrm{ETOH}$ in the laboratory. Samples were sorted, and the fauna identified into species whenever possible. The biomass (wet weigth) was determined by measuring preserved specimens divided into five major taxonomic groups including Annelida, Nemertean, Isopoda, Amphipod and Others (AMARAL; ROSSI-WONGTSCHOWSKI, 2004). Salinity and water temperature were determined with a multiparameter. Wave height $(\mathrm{Hb})$, period $(\mathrm{T})$ and beach topography were also determined in each beach and campaign by standard protocols (EMERY, 1961). Beach stage $(\Omega)$ was determined by Dean's parameter (WRIGHT; SHORT, 1984).

Sediment samples were also sampled for grain size, total organic matter and sediment chlorophyll- $a$ analyses. Composed sediment samples were taken randomly from the transects in each area (8-9 replicates) with a $7 \mathrm{~cm}$ corer to a depth of $10 \mathrm{~cm}$. Sediment samples were frozen at $-20^{\circ} \mathrm{C}$ until analyses. Grain size was determined by standard washing, drying $\left(60^{\circ} \mathrm{C}\right)$ and sieving protocols. Total organic matter was determined by the mass difference of dried $\left(60^{\circ} \mathrm{C}\right)$ and calcined $\left(450^{\circ} \mathrm{C}\right)$ sediments (SUGUIO, 1973). Sediment chlorophyll- $a$ and pheopigments were extracted from frozen sediment samples after addition of acetone following standard protocols (QUINTANA et al., 2015). After extraction, the absorbance pf Chl-a extracts was measured in a spectrophotometer (665 and 750nm) before and after acidification $(10 \% \mathrm{HCl})$, and final Chl-a concentration was calculated following LORENZEN (1967).

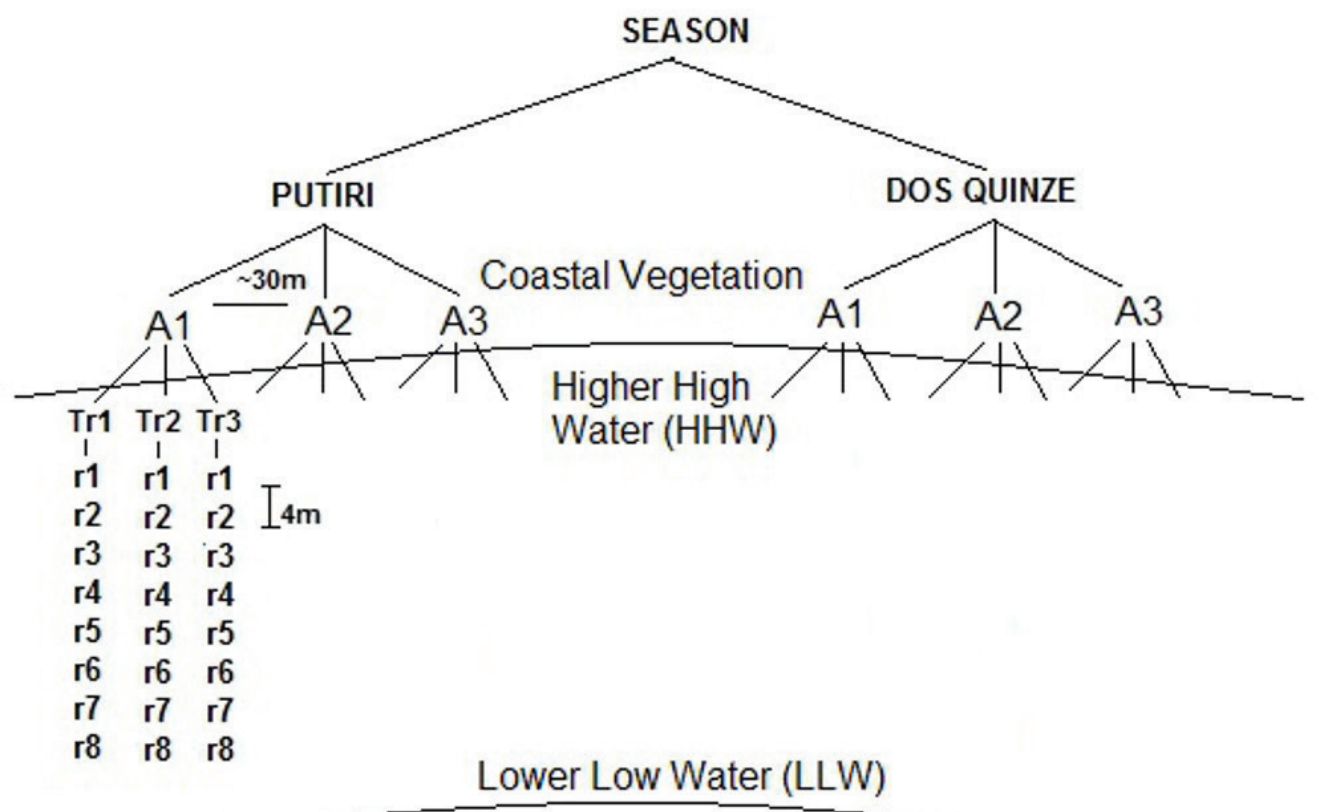

Figure 2. Sampling design showing the positions of three areas sampled alongshore in each beach with three random transects and across-shore replicates at every 4 meters between the higher high water mark and the lower low water mark. A: area; Tr: transects; r: replicates. 


\section{STATICAL ANALYSES}

Spatial and temporal variations on macrofaunal abundance and abiotic variables (grain size, total organic matter and humidity) from the beaches were tested by twoway ANOVA. Seasonal changes were tested between the six campaigns in each beach (winter and summer seasons). Hierarchical spatial changes within each beach were tested across areas level $(n=3)$, transects level $(n=3)$ and beach level $(\mathrm{n}=2)$ for abiotic data, and area level $(\mathrm{n}=3)$ for fauna density. Multivariate analyses were applied in assemblage abundance data, environmental indicators and diversity indices to test the response for environmental conditions. To test variability in assemblage composition, abundance data were forth root transformed and Bray-Curtis coefficient were applied (BARROS et al., 2001). The data was plotted using multidimensional scaling (MDS) to visualize difference between beaches and seasons. A Similarity Percentage (SIMPER) analysis was used to identify the taxa that most contributed to dissimilarities among beaches and seasons (CLARKE; GORLEY, 2006). A permutation analysis (PERMANOVA) was used to test hierarchical significance in spatial and temporal variations in macrofaunal abundance, biomass, species richness, Margalef dominance Index and Shannon diversity. The Permanova was run with a nested design, with transects $(n=3$, random) nested in areas $(n=3$, random), nested in beach $(\mathrm{n}=2$, random), and nested in season $(\mathrm{n}=2$, fixed). All these analysis were run with PRIMER 6.0 \& PERMANOVA software (CLARKE;WARWICK, 2001;
CLARKE; GORLEY, 2006). The influence of environmental variables in the composition and distribution of the fauna were tested by a Canonical Correspondent Analysis (CCA), with PAST software.

\section{RESULTS}

\section{CHANGES IN BEACH DYNAMICS}

We observed small variations in beach morphodynamics, sediment grain size and organic matter content on all spatial scales and on both seasons at the beaches studied (Table 1). Putiri and Dos Quinze beaches were typically intermediate to dissipative, in summer and winter, respectively (Dean's 2.9 to 9.6). Sediment grain size followed seasonal changes in morphodynamics with higher medium sand in summer at Putiri beach $(41 \% ; \mathrm{F}=5,67 \mathrm{p}=0,0001)$. Sediment organic matter was also higher during summer at Putiri $(\mathrm{p}=0,0001 \mathrm{~F}=11,75)$, followed by a decrease in the humidity ( $p=0,0001 \mathrm{~F}=21,91)$ in this same season. There was an increase in sediment humidity in the summer at Dos Quinze beach $(\mathrm{p}=0,0001 \mathrm{~F}=54,42)$. In general, the sediment was moderately selected at Putiri beach whereas poorly selected at Dos Quinze beach in both seasons. The beaches profiles indicated periods of erosion or accretion during the period sampled. On Putiri beach, beach erosion during winter and accretion on summer were more evident if compared to Dos Quinze beach. Putiri beach had a longer beach profile (31 and $33 \mathrm{~m}$, summer and winter, respectively), if compared to Dos Quinze beach (24 and $30 \mathrm{~m}$, summer and winter, respectively; Figure 3). 


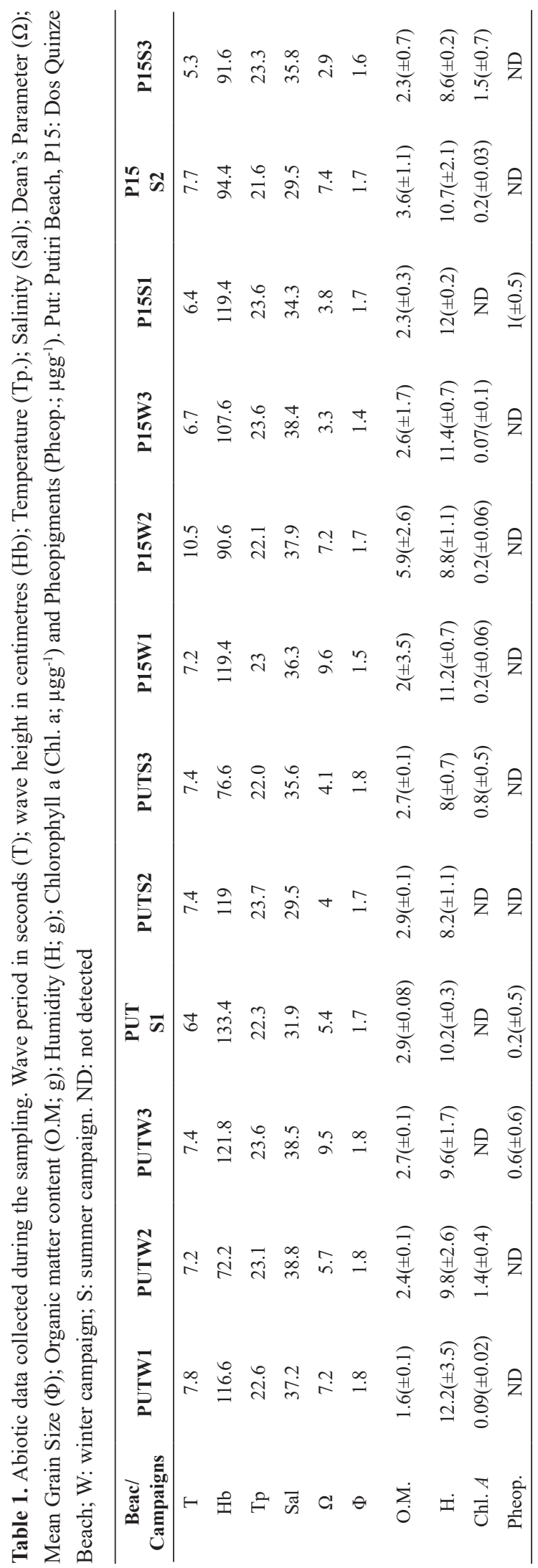




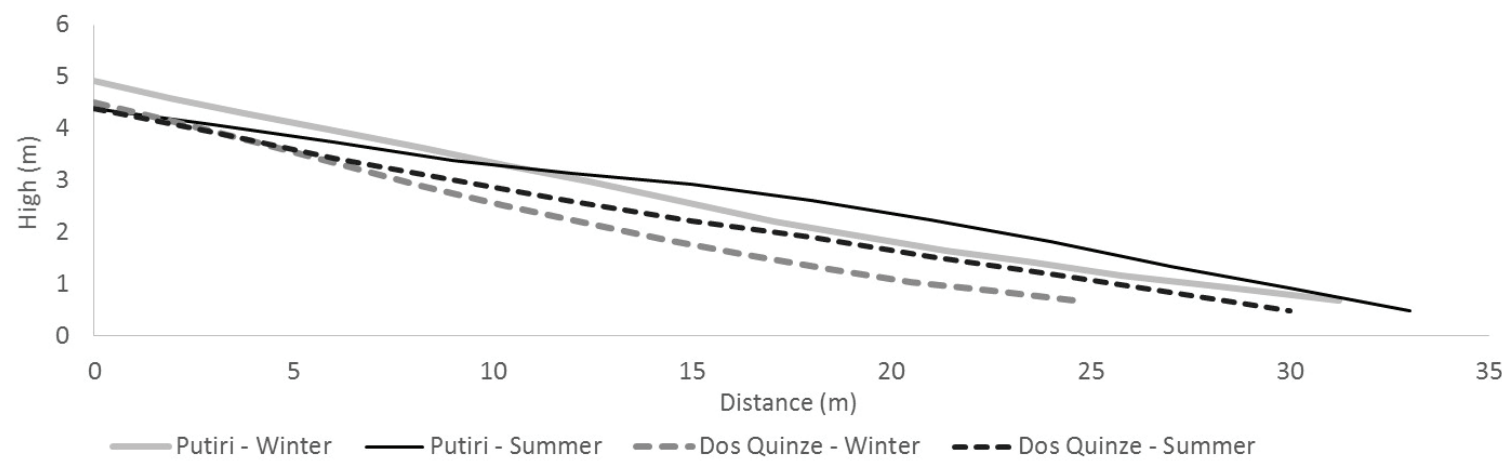

Figure 3. Putiri and Dos Quinze beach profiles in summer and winter.

\section{MACROFAUNAL SPATIAL-TEMPORAL DYNAMICS}

We found local (across-shore) to regional (between beaches) differences on macrofaunal abundance, biomass, species richness, diversity and assemblage composition between the two sandy beaches studied. Overall, macrofaunal abundance was significantly different between the two sand beaches studied with higher densities at dos Quinze beach ( $p=0,001 ; F=29,9$; Table 3). Macrofaunal assemblages were typically dominated by polychaetes $(33 \%)$, nemerteans $(23 \%)$ and isopods $(22 \%)$. Isopods were the second most abundant group at Puriti beach (24\%) and nemerteans at Dos Quinze beach (25\%).
Macrofaunal biomass followed spatial patterns in abundance and changes between the two beaches studied $(\mathrm{p}=0,02 \mathrm{~F}=4,3$; Table 3 ). Isopods and annelids contributed most to macrofaunal biomass on Putiri and Dos Quinze beaches ( $>70 \%$ of total macrofaunal biomass). At Putiri beach, macrofaunal biomass was similar between winter and summer seasons, whereas biomass increased markedly on summer at Dos Quinze beach $(p=0.023$; Table 2; Figure 4). During the winter season, Putiri beach showed a higher isopod biomass if compared to Dos Quinze beach, whereas Annelid biomass was higher at Dos Quinze beach. In the summer season, Dos Quinze beach showed a higher isopod biomass and a smaller Annelid biomass, if compared to Putiri beach.

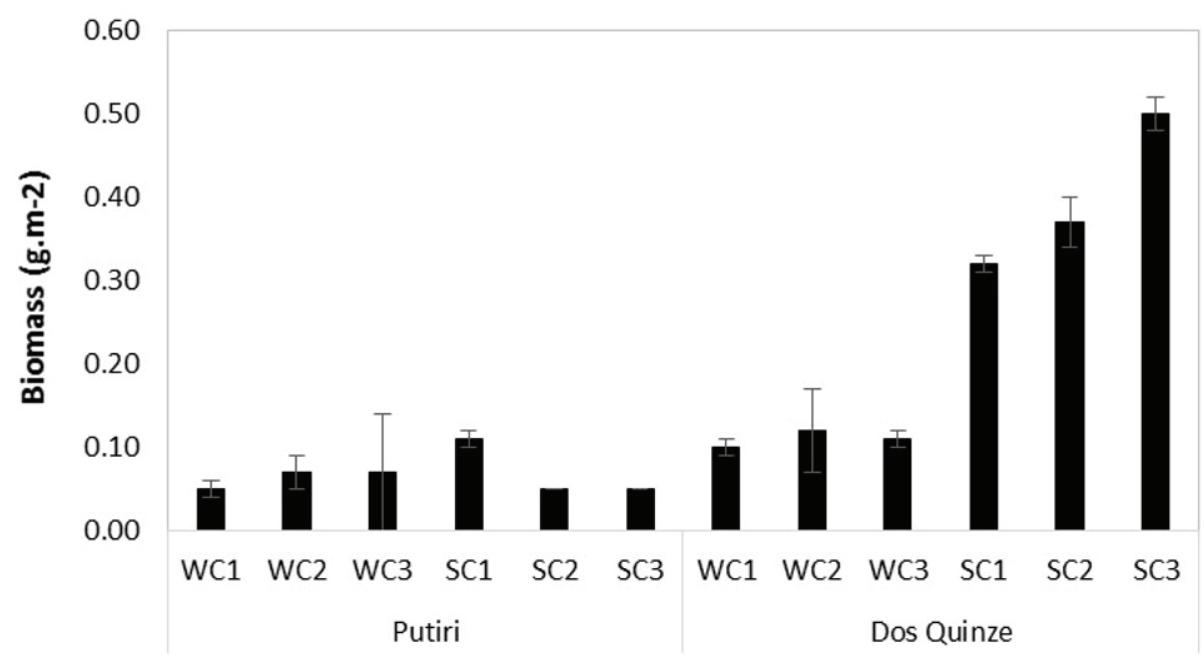

Beach/Campaign

Figure 4. Macrofaunal Biomass (g.m-2) in each campaign of summer and winter in both beaches. WC: winter campaign; SC: summer campaign. 
Species richness and diversity varied at the scale of tens of meters (across-shore) at Putiri and dos Quinze beaches ( $p=0,002 \mathrm{~F}=4,2$; Table 3), with no differences between beaches or seasons. Polychaetes dominated the sand beach macrofauna, followed by nemerteans and isopods. The most dominant polychaetes were the genera's Scolelepis (39\%), Psionidens (35\%), and their abundance decreased during winter on both beaches. The isopods Excirolana (17\%) and Alcirona (4\%) increased in abundance during summer on both beaches (Table 2). Macrofaunal assemblages were highly similar between both sand beaches, with the spatial changes in abundance most responsible for the multivariate differences regionally (ANOSIM, $\mathrm{p}=0,001$; Figure 5). Polychaetes were mainly responsible for the seasonal and spatial dissimilarity between beaches.

Table 2. Macrofaunal diversity and assemblage indexes: Species Richness, Margalef Indices, Shannon Diversity, Total Abundance and Macrofaunal biomass. PUT: Putiri Beach; P15: Dos Quinze Beach; W: winter campaign; S: summer campaign.

\begin{tabular}{|c|c|c|c|c|c|c|c|c|c|c|c|c|}
\hline $\begin{array}{c}\text { Beach/ } \\
\text { Campaign }\end{array}$ & PUTW1 & PUTW2 & PUTW3 & $\begin{array}{c}\text { PUT } \\
\text { S1 }\end{array}$ & $\begin{array}{l}\text { PT } \\
\text { S2 }\end{array}$ & PUTS3 & $\begin{array}{l}\text { P15 } \\
W 1\end{array}$ & $\begin{array}{l}\text { P15 } \\
\text { W2 }\end{array}$ & $\begin{array}{l}\text { P15 } \\
\text { W3 }\end{array}$ & $\begin{array}{c}\text { P15 } \\
\text { S1 }\end{array}$ & $\begin{array}{c}\text { P15 } \\
\text { S2 }\end{array}$ & $\begin{array}{c}\text { P15 } \\
\text { S3 }\end{array}$ \\
\hline $\begin{array}{c}\text { Specie } \\
\text { Richness }\end{array}$ & 35 & 22 & 23 & 18 & 13 & 25 & 26 & 27 & 20 & 16 & 15 & 25 \\
\hline $\begin{array}{l}\text { Margalef } \\
\text { indices }\end{array}$ & 8.1 & 5.4 & 5.6 & 4.6 & 3.5 & 6.1 & 6.2 & 6.4 & 4.9 & 3.9 & 3.8 & 6.0 \\
\hline $\begin{array}{l}\text { Shannon } \\
\text { Diversity }\end{array}$ & 3.5 & 3.0 & 3.0 & 2.8 & 2.5 & 3.1 & 3.2 & 3.2 & 2.9 & 2.7 & 2.6 & 3.1 \\
\hline $\begin{array}{c}\text { Total } \\
\text { Abundance } \\
\text { (ind.m-2) }\end{array}$ & 13089 & 13630 & 14522 & 11337 & 7579 & 10636 & 19586 & 21401 & 17611 & 24458 & 21369 & 17101 \\
\hline $\begin{array}{c}\text { Biomass } \\
\text { (g.m-2) }\end{array}$ & $\begin{array}{c}0.05 \\
( \pm 0.01)\end{array}$ & $\begin{array}{c}0.07 \\
( \pm 0.02)\end{array}$ & $\begin{array}{c}0.07 \\
( \pm 0.02)\end{array}$ & $\begin{array}{c}0.11 \\
( \pm 0.01)\end{array}$ & 0.05 & 0.05 & $\begin{array}{c}0.10 \\
( \pm 0.01)\end{array}$ & $\begin{array}{c}0.12 \\
( \pm 0.05)\end{array}$ & $\begin{array}{c}0.11 \\
( \pm 0.01)\end{array}$ & $\begin{array}{c}0.32 \\
( \pm 0.01)\end{array}$ & $\begin{array}{c}0.37 \\
( \pm 0.03)\end{array}$ & $\begin{array}{c}0.50 \\
( \pm 0.02)\end{array}$ \\
\hline
\end{tabular}

Table 3. Hierarchical permutation analyses of fauna abundance, species richness, Margalef Indices, Shannon Diversity and Biomass.

\begin{tabular}{|c|c|c|c|c|}
\hline Components of variation & GI & QM & $\mathbf{F}$ & $\mathbf{P}$ \\
\hline \multicolumn{5}{|l|}{ Total Abundance } \\
\hline Season (Se) & 1 & 1307.3 & 0.139 & 1 \\
\hline $\operatorname{Beach}(\mathrm{Be}(\mathrm{Se}))$ & 2 & 9396 & 29.932 & 0.001 \\
\hline Area $(\operatorname{Ar}(\mathrm{Be}(\mathrm{Se})))$ & 8 & 313.91 & 0.788 & 0.663 \\
\hline Transect $(\operatorname{Tr}(\operatorname{Ar}(\mathrm{Be}(\mathrm{Se}))))$ & 24 & 397.93 & 1.272 & 0.149 \\
\hline Res & 72 & 312.84 & & \\
\hline \multicolumn{5}{|l|}{ Specie richness } \\
\hline Season $(\mathrm{Se})$ & 1 & 2055.6 & 6.2487 & 0.332 \\
\hline Beach $(\mathrm{Be}(\mathrm{Se}))$ & 2 & 328.97 & 0.90595 & 0.443 \\
\hline Area $(\operatorname{Ar}(\mathrm{Be}(\mathrm{Se})))$ & 8 & 363.12 & 4.2857 & 0.002 \\
\hline Transect $(\operatorname{Tr}(\operatorname{Ar}(\mathrm{Be}(\mathrm{Se}))))$ & 24 & 84.729 & 0.65311 & 0.912 \\
\hline Res & 72 & 129.73 & & \\
\hline \multicolumn{5}{|l|}{ Margalef Indices } \\
\hline Season $(\mathrm{Se})$ & 1 & 1564.8 & 13.891 & 0.355 \\
\hline $\operatorname{Beach}(\mathrm{Be}(\mathrm{Se}))$ & 2 & 112.64 & 0.36883 & 0.762 \\
\hline Area $(\operatorname{Ar}(\mathrm{Be}(\mathrm{Se})))$ & 8 & 305.41 & 4.3682 & 0.002 \\
\hline Transect $(\operatorname{Tr}(\operatorname{Ar}(\mathrm{Be}(\mathrm{Se}))))$ & 24 & 69.916 & 0.63351 & 0.931 \\
\hline Res & 72 & 110.36 & & \\
\hline
\end{tabular}




\begin{tabular}{|c|c|c|c|c|}
\hline Components of variation & GI & QM & $\mathbf{F}$ & $\mathbf{P}$ \\
\hline Season $(\mathrm{Se})$ & 1 & 563.94 & 6.785 & 0.338 \\
\hline Beach $(\mathrm{Be}(\mathrm{Se}))$ & 2 & 83.116 & 0.72712 & 0.549 \\
\hline Area $(\operatorname{Ar}(\mathrm{Be}(\mathrm{Se})))$ & 8 & 114.31 & 6.1265 & 0.001 \\
\hline Transect $(\operatorname{Tr}(\operatorname{Ar}(\mathrm{Be}(\mathrm{Se}))))$ & 24 & 18.658 & 0.53681 & 0.947 \\
\hline Res & 72 & 34.757 & & \\
\hline \multicolumn{5}{|l|}{ Biomass } \\
\hline Season $(\mathrm{Se})$ & 1 & 12270 & 2.1871 & 0.345 \\
\hline Beach $(\mathrm{Be}(\mathrm{Se}))$ & 2 & 5610.2 & 4.3356 & 0.023 \\
\hline $\operatorname{Area}(\operatorname{Ar}(\mathrm{Be}(\mathrm{Se})))$ & 8 & 1294 & 1.3843 & 0.206 \\
\hline Transect $(\operatorname{Tr}(\operatorname{Ar}(\mathrm{Be}(\mathrm{Se}))))$ & 24 & 934.73 & 1.26 & 0.137 \\
\hline Res & 72 & 741.84 & & \\
\hline
\end{tabular}

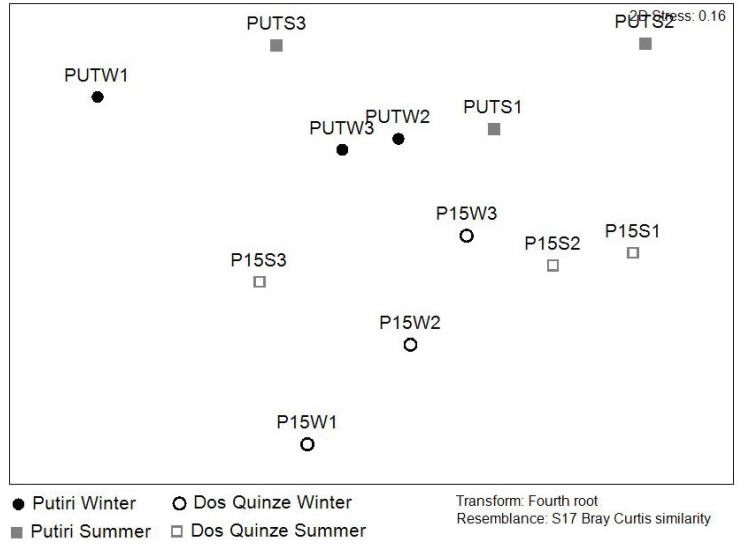

Figure 5. Non-metric Multi-Dimensional Scaling (MDS) between Putiri and Dos Quinze beaches in each season, winter and summer. PUT: Putiri beach; P15: Dos Quinze beach; W: winter campaign; S: summer campaign.
Environmental variables, including grain size, chlorophyll $a$, and sediment organic matter were mainly responsible for assemblage distribution on both sandy beaches $(80 \%, \mathrm{CCA})$. Fine sand and pheopigments influenced most macrofaunal assemblages in Putiri beach, whereas organic matter content influenced macrofaunal assemblages at Dos Quinze beach during the winter and summer. Macrofaunal species composition was related to sand grain size and organic matter content, with polychaetes associated with finer sand and oligochaetes and nemerteans with mud. The axis 1 were related with the fine sand factor and the axis 2 with medium sand $(0.39 ; 0.79$, respectively; Figure 6 ; Table 4$)$. The third axis was associated with the very coarse particles $(0.36)$ and the fourth with pheopgiments $(0.35)$.

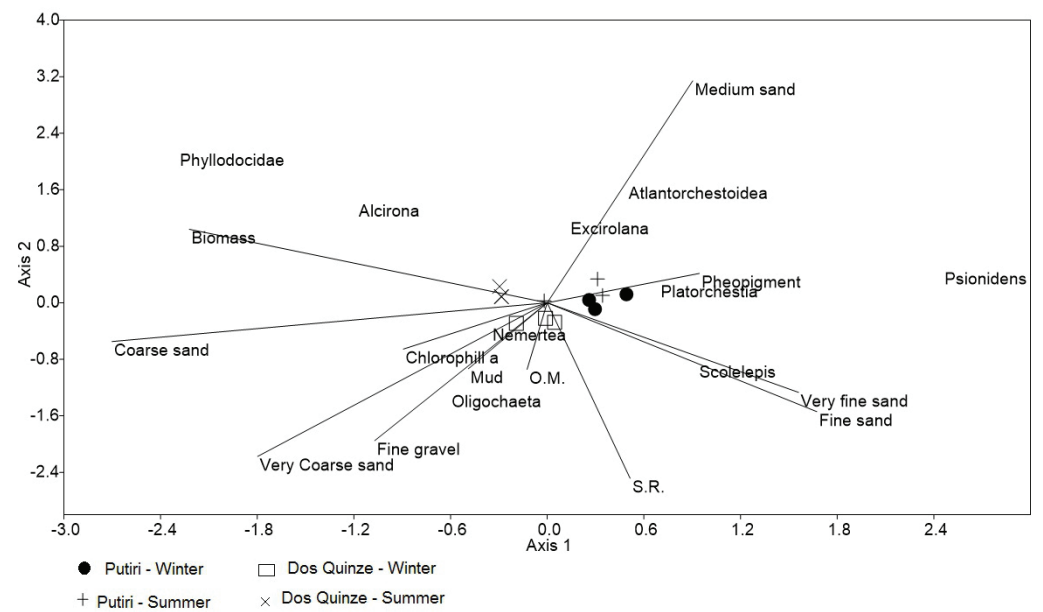

Figure 6. Canonical Correspondence Analyses of environmental data and abundance data in Putiri and Dos Quinze beaches in each season. S. R.: species richness; O. M.: organic matter. 
Table 4. Eigenvalues of CCA. S.R.: species richness; O. M.: organic matter; F. G.: fine gravel; Chlr: clorophyll a; Pheop.: pheopigments.

\begin{tabular}{lcccc}
\hline Variable/Axis & Axis1 & Axis 2 & Axis 3 & Axis 4 \\
\hline SR & 0.13 & -0.62 & -0.45 & -0.22 \\
O.M. & -0.03 & -0.24 & 0.10 & 0.07 \\
F.G. & -0.27 & -0.49 & 0.21 & 0.00 \\
Sand & -0.06 & -0.18 & 0.04 & -0.02 \\
Mud & -0.12 & -0.23 & -0.53 & -0.01 \\
Biomass & -0.56 & 0.26 & -0.43 & 0.24 \\
Chlr. & -0.22 & -0.16 & -0.32 & -0.37 \\
Pheop. & 0.24 & 0.10 & 0.31 & 0.35 \\
\hline
\end{tabular}

\section{DISCUSSION}

Putiri and Dos Quinze beaches were highly similar in respect to their sedimentary and environmental variables, and exhibited small seasonal morphodynamic changes within intermediate and dissipative states. These seasonal changes resulted in variable predominance of finer sediments during winter (dissipative), or an increase in sediment grain size, leading to sand accumulation during summer, which likely changed water and organic accumulation on the beaches (MCLACHLAN; BROWN, 2006). However, seasonal increases on sediment organic matter were not uniform between beaches, nor were the response of macrofaunal assemblages. Spatial differences between organic matter availability were significantly associated with higher macrofaunal abundance and biomass in one of the beaches studied, as observed on dissipative and intermediate sandy beaches (BROWN; MCLACHLAN, 1990; OMENA; AMARAL, 1997; BORZONE et al., 2003; CISNEROS et al., 2011). The seasonal differences and opposite patterns of macrofaunal abundance and biomass between the two nearby sandy beaches illustrate how complex are the benthic dynamics of sand beaches and highlight the need to include multiple scales of study to investigate changes in these ecosystems (SCHLACHER et al., 2008).

Spatial changes in macrofaunal richness and diversity were evident on across-shore scales at both sandy beaches, which partially supported our hypothesis of significant spatial changes in assemblage structure and weaker variability at seasonal scales. Morphodynamic state is one of the key physical forces controlling the sandy beach macrofauna, with an increase in species richness and abundance from reflective to dissipative beaches, due to hard swash climate and coarse sands (CARCEDO et al.,2014; DEFEO; MCLACHLAN, 2005; DEFEO et al., 2001). Comparing the two sandy beaches with other sandy beaches, Putiri and Dos Quinze showed higher species richness than reflective beaches at Rio de Janeiro State, both in winter and in summer season (VELOSO et al., 1997; VELOSO; CARDOSO, 2001). The Putiri and dos Quinze sand beaches had a similar species richness with intermediate sandy beaches at California (SCHOOLER et al., 2014), suggesting similar physical and biological controls on the fauna and within expected latitudinal gradients of diversity.

Macrofaunal density was highest during winter in only one of the beaches, also evidencing contrasting spatial patterns between nearby sandy beaches. Sandy beaches with low profiles, common in intermediate and dissipative beaches typically support a high abundance, rich and diverse macrofauna due to less physical stress (MCLACHLAN; DORVLO, 2005; MCLACHLAN; BROWN, 2006). Although Putiri and Dos Quinze beaches were very similar in their beach state, it is likely that increased organic input led to higher macrofaunal abundance at dos Quinze beach. Therefore, although sediment grain size was similar during the period studied, the organic matter availability and quality (i.e. as measured by chla- $a$ content) influenced differences on macrofaunal abundance between the two sand beaches (VELOSO et al., 2003; RODIL; LASTRA, 2004; MCLACHLAN; DORVLO, 2005; LERCARI; DEFEO, 2006). However, patterns of diversity and species richness varied at local scales, supporting the strong smallscale spatial changes in macrofaunal assemblages associated with organic matter content and sediment grain size (LERCARI; DEFEO, 2006, MCLACHLAN; DORVLO, 2005; VELOSO et al., 2003).

Tropical sand beaches exhibit lower temporal fluctuations in density and diversity because seasonality is not pronounced (VELOSO; CARDOSO, 2001). At temperate and subtropical regions, including southern regions of Brazil, temporal changes on macrofaunal diversity are evident (DEFEO; MCLACHLAN, 2005). In the sand beaches of the EME studied, benthic assemblage composition was similar across spatial and temporal scales, and was dominated by typical Crustacean and Annelid taxa. Crustaceans were the most representative taxa in both sand beaches and significantly contributed total macrofaunal biomass. The cirolanidae Excirolana sp. was one of the 
most dominant isopods and is typical of fine sandy beaches on the Southeast Brazilian Marine Ecoregion and Uruguay beaches (DEFEO et al., 1997; FERNANDES; GOMES, 2006). The dominant polychaetes Scolelepis sp. are also widely common on Atlantic sandy beaches and were highly abundant at both sand beaches, indicating that the sandy beach macrofauna of the EME shares several species with other sandy beaches in Brazil (SOUZA; GIANUCA, 1995; BORZONE et al., 1996; FERNANDES; GOMES, 2006). Other common sand beach taxa including Talitridae, Ocypodidae and Cirolanidae also occur abundantly in most beaches of Southern Brazil (SOUZA; GIANUCA, 1995; BARROS et al., 2001; BORZONE et al., 2003). Some temperate taxa were also abundant, including oligochaetes and nemerteans, probably due the high content of organic matter. Nemerteans are abundant in fine sand sandy beaches and are common in low latitude beaches (DEFEO; MCLACHLAN, 2005; MCLACHLAN; BROWN, 2006).

The benthic macrofauna of the two sandy beaches studied showed expected responses to food availability and sediment grain size, supporting similarities with other oligotrophic sandy beaches (CISNEROS et al., 2011). Although the macrofaunal composition is strongly similar at the regional scale, spatial-temporal changes in abundance of polychaetes and crustaceans contribute to dissimilarity of assemblages and highlight how complex these abiotic interactions occur on these ecosystems (DEFEO; MCLACHLAN, 2005). This study presented the most comprehensive evaluation of multiple spatial scales of variability of the macrofauna on sandy beaches of Espirito Santo State to date, which may have been impacted by a large scale mining tailing accident that released toxic plumes from the Rio Doce River $150 \mathrm{Km}$ North (MartaALMEIDA et al., 2016). The hierarchical sampling design was essential to differentiate spatial patterns that occurred at across-shore and between sandy beaches, revealing contrasting changes between two nearby sandy beaches along seasonal scales. As a result, monitoring and impact assessment programs on coastal areas, including sandy beaches, need to incorporate such sampling designs in order to adequately assess impacts on benthic communities from regional and climatic stressors.

\section{ACKNOWLEDGEMENTS}

We thank all participants of intensive fieldwork campaigns for their valuable effort. We thank the reviewers and the editors of this special volume for their carefull comments that improved this manuscript. MSC was supported by a CAPES (Coordenação de Aperfeiçoamento de Pessoal de Nível Superior) master's scholarship. AFB was supported by a CNPq PQ grant 301412/2013-8.

\section{REFERENCES}

ALBINO, J.; PAIVA, D. S.; MACHADO, G. M. Geomorfologia, Tipologia, Vulnerabilidade erosiva e ocupação urbana das praias do litoral do Espírito Santo, Brasil. Revta Geografares, n. 2. Vitória, 2001.

ALONGI, D. M. Coastal ecosystem processes. New York: CRC Press, 1998.

AMARAL, A. C. Z.; ROSSI -WONGTSCHOWSKI, C. L. D. B. Biodiversidade Bentônica da Região Sudeste-Sul do Brasil Plataforma Externa e Talude Superior. Revizee - Score Sul, Instituto Oceanográfico, USP. 2004.

AMARAL, A. C. Z; ET. AL. Brazilian Sandy Beaches: characteristics, ecosystem services, impacts, knowledge and priorities. Braz. J. Oceanogr., v. 64, p. 5-16, 2016.

BARROS, F.; BORZONE, C. A.; ROSSO, S. Macroinfauna of six beaches near Guaratuba Bay, southern Brazil. Braz. Arch. Biol. Technol., v. 44, n. 4, p. 351-364, 2001.

BARBOSA, F. R.; GÓMEZ, J.; LERCARI, D. DEFEO, O. Disentangling diversity patterns in sandy beaches along environmental gradients. PloS ONE, v.7, n. 7, 2012.

BERNARDINO, A.F.; NETTO, S.A.; PAGLIOSA, P.R.; BARROS, F.; CHRISTOFOLETTI, R.A., FILHO, J.S.R.; COLLING, A.; LANA, P.C. Predicting ecological changes on benthic estuarine assemblages through decadal climate trends along Brazilian Marine Ecoregions. Estuar. coast. Shelf Sci., 166: 74-82, 2015.

BERNARDINO, A.F.; PAGLIOSA, P.R.; CHRISTOFOLETTI, R.A.; BARROS, F.; NETTO, S.A.; MUNIZ, P.; LANA, P.C. Benthic estuarine communities in Brazil: moving forward to long term studies to assess climate change impacts. Braz. J. Oceanogr., v. 64, p.83-97, 2016. http://dx.doi.org/10.1590/ S1679-875920160849064sp2

BORZONE, C. A.; MELOÀ, S. G; REZENDE, K. V.; VALE, R.; KRUL, R. Macrobenthic intertidal communities from wave to tide dominated beach environments. A case study in two Brazilian beaches. J. coast. Res., p. 472-480, Spr 2003.

BORZONE, C. A.; SOUZA, J. R. B.; SOARES, A. G. Morphodynamic influence on the structure of inter and subtidal macrofaunal communities of subtropical sandy beaches. Revta Chilena Hist Nat, v. 69, n. 4, p. 565-577, Dec 1996.

BROW, A.C., MCLACHLAN, A. Ecology of Sandy Shores. Elsevier, Amsterdam. 1990

CARCEDO, C.; FIORI, S.; BREMEC, C. Macrobenthic surf zone communities of temperate sandy beaches: spatial and temporal patterns. Mar. Ecol., p. 1-14, 2014.

CLARKE, K.R.; GORLEY, R.N. PRIMER v.6: User manual/Tutorial, Plymouth. 2006.

CLARKE, K.R.; WARWICK, R.M. Change in marine communities: an approach to statistical analysis and interpretation. 2ed. Plymouth, Plymouth Marine Laboratory, 2001. 
CISNEROS, K. O.; SMIT, A. J.; LAUDIEN, J.; SCHOEMAN, D. S. Complex, dynamic combination of physical, chemical and nutritional variables controls spatio-temporal variation of sandy beach community structure. PloS ONE, v. 6, n. 8, 2011.

DEFEO, O.; BRAZEIRO, A; ALAVA DE A.; RIESTRA, G. Is sandy beach macrofauna only physically controlled? Role of substrate and competition in isopods. Estuar. coast. Shelf Sci, v. 45, n. 4, p. 453-462, Oct 1997.

DEFEO, O.; GOMEZ, J. Morphodynamics and habitat safety in sandy beaches: life-history adaptations in a supralittoral amphipod. Mar. Ecol. Progr. Ser., v. 293, p. 143-153, 2005.

DEFEO, O.; MCLACHLAN, A. Patterns, processes and regulatory mechanisms in sandy beach macrofauna: a multi-scale analysis. Mar. Ecol. Progr. Ser., v. 295, p. 1-20, 2005.

Global patterns in sandy beach macrofauna: Species richness, abundance, biomass and body size. Geomorp., v. 199, p. 106-114, Oct 2013.

DEFEO, O.; MCLACHLAN, A.; SCHOEMAN, D. S.; SCHLACHER, T. A.; DUGAN, J.; JONES, A.; LASTRA, M.; SCAPINI, F. Threats to sandy beaches ecosystems: a review. Estuar. coast. Shelf Sci, v. 81, n. 1, p. 1-12, 2009.

DEFEO, O, GOMEZ J, LERCARI, D. Testing the swash exclusion hypothesis in sandy beach populations: the mole crab Emerita brasiliensis in Uruguay. Mar Ecol Prog Ser, 212:159-170, 2001.

EMERY, K. O. A simple method of measuring beach profiles. University of Southern California. Los Angeles. 1961.

FERNANDES, R. S. R; GOMES, A. S. Community structure of macrobenthos in two tropical sandy beaches with different morphodynamic features, Rio de Janeiro, Brazil. Mar. Ecol., v. 27, p. 160-169, 2006

GOMES, L. E. O.; CORREA, L. B.; SÁ, F.; NETO, R. R.; BERNARDINO, A. F. The impacts of the Samarco mine tailing spill on the Rio Doce estuary, Eastern Brazil. Mar. Poll. Bull. v. 120, p. 28-36, 2017.

LERCARI, D.; DEFEO, O. Large-scale diversity and abundance trends in sandy beach macrofauna along full gradients of salinity and morphodynamics. Estuar. coast. Shelf Sci, v. 68, n. 1-2, p. 27-35, Jun 2006.

LORENZEN, C. J. Determination of chlorphyll and pheo-pigments - spectrophotometric equations. Limnol. Oceanogr., v. 12, n. 2, p. 343-\&, 19671967.

MARTA-ALMEIDA, M.; MENDES, R.; AMORIM, F.N.; CIRANO, M.; DIAS, J.M. Fundão Dam collapse: Oceanic dispersion of River Doce after the greatest Brazilian environmental accident. 2016. Mar. Pollut. Bull., v. 112, p.359-364.

MCLACHLAN, A. Water filtration by dissipative beaches. Limnol. Oceanogr., v. 34, n. 4, p. 774-780, Jun 1989.

MCLACHLAN, A.; BROWN, A. C. The Ecology of Sandy shores. New York. Elsevier, 373 p., 2006.

MCLACHLAN, A.; DORVLO, A. Global patterns in sandy beach macrobenthic communities. J. coast. Res., v. 21, n. 4, p. 674687, Jul 2005.

MCLACHLAN, A; ERASMUS, T. Sandy beaches as ecosystems. W Junk, The Hague. 1983.

MINISTÉRIO DO MEIO AMBIENTE. Áreas prioritárias para a conservação, uso sustentável e repartição de benefícios da biodiversidade brasileira: atualização, Portaria MMA 09, de 23 de janeiro de 2007. MMA. Brasília, 300 p., 2007.

MUEHE, D. Beach Morphodinamic Research in Brazil: evolution and Applicability. J. coast. Res., v. SI, n. 35, p. 32-42, 2003.
MUEHE, D. Erosão e progradação no litoral brasileiro. Brasília: Ministério do Meio Ambiente (MMA), 2006.

OMENA, E. P.; AMARAL, A. C. Z. Distribuição espacial de polychaeta (Annelida) em diferentes ambientes entremarés de praias de São Sebastião (SP). Oecologia Brasiliensis, v. 3, p. 183-196, 1997.

QUINTANA, C. O.; BERNARDINO; A. F.; MORAES, P. C.; VALDEMARSEN, T.; SUMIDA, P. Y. G. Effects of coastal upwelling on the structure of macrofaunal communities in SE Brazil. J. Mar. Sys., v.143, p. 120-129.

RODIL, I. F.; LASTRA, M. Environmental factors affecting benthic macrofauna along a gradient of intermediate sandy beaches in northern Spain. Estuar. coast. Shelf Sci, v. 61, n. 1, p. 37-44, Sep 2004.

SCHLACHER, T. A. et al. Sandy beaches at the brink. Divers. Distrib., v. 13, n. 5, p. 556-560, Sep 2007.

SCHLACHER, T.A., SCHOEMMAN, D.S., DUGAN, J.E., LASTRA, M., JONES, A., SCAPINIi, F., MCLACHLAN, A.. Sandy beach ecosystems: key features, sampling issues, management challenges and climate change impacts. Mar. Ecol. - Evolutionary Perspective 29 (S1), 70-90, 2008.

SCHOOLER, N. K; DUGAN, J. E.; HUBBARD, D. M. Detecting change in intertidal species richness on sandy beaches: calibrating across sampling designs. Estuar. coast. Shelf Sci, v. 150, p. 58-66, 2014.

SOUZA, J. R. B.; GIANUCA, N. M. Zonation and seasonal variation of intertidal macrofauna on a sandy beach of Paraná State, Brazil. Sci. Mar., v. 59, n. 2, p. 103-111, 1995.

SPALDING, M. D. et al. Marine Ecoregions of the World: A bioregionalization of coastal and shelf áreas. BioScience, n. 7, v. 57, p. 573-583, Jul-Aug 2007.

SUGUIO, K. Introdução à sedimentologia. São Paulo: E. Blücher: Ed. da USP xii. 317 p, 1973.

VELOSO, V. G.; CAETANO, C. H. S.; CARDOSO, R. S. Composition, structure and zonation of intertidal macroinfauna in relation to physical factors in microtidal sandy beaches in Rio de Janeiro state, Brazil. Sci. Mar., v. 67, n. 4, p. 393-402, Dec 2003.

VELOSO, V. G.; CARDOSO, R. S. Effects of morphodynamics on the spatial and temporal variation of the macrofuana on three sandy beaches, Rio de Janeiro State, Brazil. J. Mar. Biol. Ass. U.K., v. 81, p. 369-375, 2001.

VELOSO, V. G.; CARDOSO, R. S.; FONSECA, D. B. Adaptações e biologia da macrofauna de praias arenosas expostas com ênfase nas espécies da região entre-marés do litoral fluminense. Oecologia Brasiliensis: Ecologia de praias arenosas do litoral brasileiro, Rio de Janeiro, v. 3. p. 135-154, 1997.

Spatio-temporal characterization of intertidal macrofaunal at Prainha becha (Rio de Janeiro Satate). Oecologia Brasiliensis, v.3, p. 213-225, 1997.

VELOSO, V. G. et al. Responses of talitrid amphipods to a gradient of recreational pressure caused by beach urbanization. Mar. Ecol. -an Evolutionary Perspective, v. 29, p. 126-133, Jul 2008.

VIEIRA, J. V.; BORZONE, C. A.; LORENZI, L.; CARVALHO, F. G. Human impact on the benthic macrofauna of two beach environments with different morphodynamic characteristics in southern Brazil. Braz. J. Oceanogr., v. 60, n. 2, p. 137-150, 2012.

WRIGHT, L. D.; SHORT, A. D. Morphodynamic variability of surf zone and beaches, a synthesis. Marine Geology, v. 56, p. $93-118,1984$. 